\title{
A 50\% higher prevalence of life-shortening chronic conditions among cancer patients with low socioeconomic status
}

\author{
WJ Louwman ${ }^{*, 1,2}$, MJ Aarts', S Houterman ${ }^{3}$, FJ van Lenthe', JWW Coebergh ${ }^{1,2}$ and MLG Janssen-Heijnen ${ }^{1,2}$ \\ 'Comprehensive Cancer Centre South (IKZ), Eindhoven Cancer Registry, PO Box 231, Eindhoven 5600 AE, The Netherlands; ${ }^{2}$ Department of Public \\ Health, Erasmus University Medical Center Rotterdam, PO Box 2040, Rotterdam 3000 CA, The Netherlands; ${ }^{3}$ MMC Academy, Máxima Medical Center, \\ PO Box 7777, Veldhoven 5500 MB, The Netherlands
}

BACKGROUND: Comorbidity and socioeconomic status (SES) may be related among cancer patients. METHOD: Population-based cancer registry study among 72153 patients diagnosed during 1997-2006.

RESULTS: LOW SES patients had 50\% higher risk of serious comorbidity than those with high SES. Prevalence was increased for each cancer site. Low SES cancer patients had significantly higher risk of also having cardiovascular disease, chronic obstructive pulmonary diseases, diabetes mellitus, cerebrovascular disease, tuberculosis, dementia, and gastrointestinal disease. One-year survival was significantly worse in lowest vs highest SES, partly explained by comorbidity.

CONCLUSION: This illustrates the enormous heterogeneity of cancer patients and stresses the need for optimal treatment of cancer patients with a variety of concomitant chronic conditions.

British Journal of Cancer (2010) I 03, 1742-1748. doi: I0.1038/sj.bjc.6605949 www.bjcancer.com

Published online 26 October 2010

(C) 2010 Cancer Research UK

Keywords: socioeconomic status; comorbidity; chronic disease; survival

People of a lower socioeconomic status (SES) generally have poorer health status and higher mortality than people of higher SES (Jemal et al, 2008; Mackenbach et al, 2008), also with respect to cancer, with in general higher incidence rate of all cancers combined among people from lower socioeconomic groups (Dalton et al, 2008). A differential distribution of known risk factors for specific neoplasms between SES groups seems a likely explanation for the above inequalities. For example, the prevalence of smokers has become higher among lower classes (Lahelma et al, 1997; Stronks et al, 1997), probably resulting in higher rates of cancer of the lung, larynx, mouth, pharynx, oesophagus, and bladder (Siemiatycki et al, 1995; Stellman and Resnicow, 1997; Tyczynski et al, 2003). However, smoking is not only related to cancer but also to chronic obstructive pulmonary diseases (COPD) and cardiovascular diseases (Doll et al, 1994). Hence, the high prevalence of comorbidity among lung cancer patients (Janssen-Heijnen et al, 1998). Socioeconomic status may thus be associated with comorbidity among cancer patients. Thus, medical doctors are presented with a heterogeneous group of cancer patients, for whom appropriate individual treatment must be chosen, taking concomitant conditions into account (Ayanian et al, 2003; Lash et al, 2003; Janssen-Heijnen et al, 2004; Lemmens et al, 2005; Louwman et al, 2005; van Spronsen et al, 2005).

We studied in a large population-based group of cancer patients the prevalence of comorbidity according to SES, not only by number of concomitant diseases, but also for specific diseases that affect patients with the various tumour sites.

*Correspondence: Dr WJ Louwman; E-mail: research@ikz.nl Revised 17 August 20 10; accepted 15 September 20 0; published online 26 October 2010

\section{MATERIALS AND METHODS}

The Eindhoven Cancer Registry records data on all patients newly diagnosed with cancer in the south of the Netherlands (2.4 million inhabitants, $15 \%$ of the Dutch population); it also records serious comorbidity according to an adaptated list (Charlson et al, 1987). Chronic obstructive pulmonary diseases, cardio- and cerebrovascular diseases, peripheral arterial disease, other malignancies, and diabetes mellitus, connective tissue diseases, rheumatoid arthritis, kidney, bowel, and liver diseases, dementia, tuberculosis and other chronic infections were also recorded. For most analyses peripheral arterial disease was included in the cardiovascular diseases, although gastrointestinal diseases were grouped (gastric diseases, Crohn's disease, ulcerative colitis, liver cirrhosis, and hepatitis). Comorbidity was defined as life-shortening disease that was present at the time of cancer diagnosis and/or received treatment or surveillance. Trained registry personnel actively collect data on diagnosis, staging, and treatment from the medical records after notification by pathologists and medical registration offices. Previous admissions, letters from and to general practitioners and other specialists, the medical history and preoperative screening were used as sources.

Patients with cancer of the oesophagus, stomach, colon or rectum, pancreas, lung, melanoma, breast, cervix uteri, corpus uteri, ovary, prostate, bladder, kidney, and non-Hodgkin's lymphoma (NHL), newly diagnosed between 1997 and 2006 $(n=72153)$, were included in this study; cancers diagnosed at autopsy $(n=369)$ were excluded.

Statistics Netherlands developed an indicator of SES, using individual fiscal data on the economic value of the home and household income, and is provided at aggregated level 
Table I Description of all cancer patients diagnosed with selected tumours between 1997 and 2006 in the Eindhoven Cancer Registry

\begin{tabular}{|c|c|c|c|c|c|c|}
\hline & \multicolumn{2}{|c|}{ Males } & \multicolumn{2}{|c|}{ Females } & \multicolumn{2}{|c|}{ Total } \\
\hline & $n$ & $\%$ & $n$ & $\%$ & $n$ & $\%$ \\
\hline \multicolumn{7}{|l|}{ Tumour localisation } \\
\hline Oesophagus & 1079 & 3 & 398 & I & 1477 & \\
\hline Stomach & 1723 & 5 & 1032 & 3 & 2755 & \\
\hline Colorectal & 6815 & 19 & 6014 & 17 & 12829 & 18 \\
\hline Pancreas & 907 & 2 & 849 & 2 & 1756 & \\
\hline Lung & 9354 & 26 & 3591 & 10 & 12945 & 18 \\
\hline Melanoma & 1405 & 4 & 1899 & 5 & 3304 & \\
\hline Breast & - & & 14859 & 41 & 14859 & 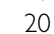 \\
\hline Cervix uteri & - & & 725 & 2 & 725 & \\
\hline Corpus uteri & - & & 2128 & 6 & 2128 & \\
\hline Ovary & - & & 1540 & 4 & 1540 & \\
\hline Prostate & 9987 & 27 & - & & 9987 & I \\
\hline Kidney & $120 \mid$ & 3 & 806 & 2 & 2007 & \\
\hline Urinary bladder & 2306 & 6 & 679 & 2 & 2985 & \\
\hline Non-Hodgkin's lymphoma & 1846 & 5 & 1413 & 4 & 3259 & \\
\hline \multicolumn{7}{|l|}{ Age } \\
\hline$<45$ & 1156 & 3 & 3884 & 11 & 5040 & \\
\hline $45-59$ & 6624 & 18 & 10578 & 29 & 17202 & \\
\hline $60-74$ & 18984 & 52 & $13 \mid 42$ & 37 & 32126 & 44 \\
\hline$>75$ & 9859 & 27 & 8329 & 23 & 18188 & 25 \\
\hline \multicolumn{7}{|l|}{ SES } \\
\hline Low & 9518 & 26 & 9953 & 28 & $1947 \mid$ & 27 \\
\hline Intermediate & 14309 & 39 & 13824 & 38 & 28133 & \\
\hline High & 10812 & 30 & 9741 & 27 & 20553 & 2 \\
\hline Institution & 1569 & 4 & 2032 & 6 & 3601 & \\
\hline Unknown & 415 & i & 383 & । & 798 & \\
\hline \multicolumn{7}{|l|}{ Comorbidity } \\
\hline \multicolumn{7}{|c|}{ Number of concomitant diseases } \\
\hline 0 & 10688 & 29 & 14826 & 41 & 25514 & 3 \\
\hline I & 10775 & 29 & 9353 & 26 & 20128 & \\
\hline$>2$ & 10992 & 30 & 7050 & 20 & 18042 & 25 \\
\hline Unknown & 4168 & 11 & 4704 & 13 & 8872 & 12 \\
\hline \multicolumn{7}{|l|}{ Concomitant disease $^{\mathrm{a}}$} \\
\hline Previous cancer & 4460 & 12 & 3565 & 10 & 7977 & II \\
\hline Cardiovascular disease & 8353 & 23 & 3854 & । & 12127 & 17 \\
\hline Peripheral arterial disease & 3445 & 9 & 1358 & 4 & 4767 & \\
\hline COPD & 5347 & 15 & 2674 & 7 & 7994 & II \\
\hline Hypertension & 6367 & 17 & 7184 & 20 & 13462 & 19 \\
\hline Diabetes mellitus & 3586 & 10 & 3482 & 10 & 7026 & 10 \\
\hline Cerebrovascular disease & 1754 & 5 & 1044 & 3 & 2779 & \\
\hline Tuberculosis & 553 & 2 & 409 & 1 & 947 & \\
\hline Central nervous system ${ }^{b}$ & 221 & 1 & 354 & । & 568 & \\
\hline Gastrointestinal disease & 2629 & 7 & 1294 & 4 & 3900 & \\
\hline Other diseases & 925 & 3 & 1078 & 3 & 1987 & \\
\hline Total & 36623 & 50 & 35933 & 50 & 72556 & 100 \\
\hline
\end{tabular}

Abbreviations: $\mathrm{COPD}=$ chronic obstructive pulmonary diseases; SES = socioeco-

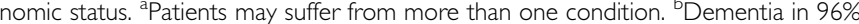
of these patients.

for each postal code (covering an average of 17 households). Socioeconomic status was categorised as low (deciles 1-3), medium (deciles 4-7), or high social class (deciles 8-10), and a separate class for postal codes for a long-term care providing institution (such as a nursing home; van Duijn and Keij, 2002). We calculated the distribution of cancer patients across socioeconomic strata according to tumour localisation, also by gender and age. Patients for whom the SES was unknown $(n=766,1 \%)$ or for whom the postal code included a care providing institution $(n=3569,5 \%)$, as well as those with unknown comorbidity ( $n=8399,12 \%)$ were excluded from the analyses of SES and comorbidity. Differences in distribution were tested with the
Table 2 Distribution of cancer patients newly diagnosed in 1997-2006 according to gender, age and socioeconomic status (SES)

\begin{tabular}{|c|c|c|c|c|c|c|c|c|}
\hline \multirow[b]{3}{*}{$\begin{array}{l}\text { Tumour } \\
\text { localisation }\end{array}$} & \multicolumn{4}{|c|}{ Males } & \multicolumn{4}{|c|}{ Females } \\
\hline & \multicolumn{2}{|c|}{$<70$} & \multicolumn{2}{|c|}{$70+$} & \multicolumn{2}{|c|}{$<70$} & \multicolumn{2}{|c|}{$70+$} \\
\hline & $\begin{array}{l}\text { No. of } \\
\text { patients }\end{array}$ & $\begin{array}{l}\% \text { low } \\
\text { SES }\end{array}$ & $\begin{array}{c}\text { No. of } \\
\text { patients }\end{array}$ & $\begin{array}{l}\text { \% low } \\
\text { SES }\end{array}$ & $\begin{array}{c}\text { No. of } \\
\text { patients }\end{array}$ & $\begin{array}{l}\% \text { low } \\
\text { SES }\end{array}$ & $\begin{array}{c}\text { No. of } \\
\text { patients }\end{array}$ & $\begin{array}{c}\% \text { low } \\
\text { SES }\end{array}$ \\
\hline Oesophagus & 589 & 23 & 342 & 37 & 170 & 30 & 161 & 43 \\
\hline Stomach & 767 & 26 & 719 & 37 & 386 & 31 & 465 & 44 \\
\hline Colorectal & 3176 & 21 & 2662 & 32 & 2266 & 24 & 2630 & 40 \\
\hline Pancreas & 433 & 24 & 339 & 36 & 325 & 28 & 374 & 44 \\
\hline Lung & 4498 & 29 & 3827 & 38 & 2226 & 35 & 923 & 50 \\
\hline Melanoma & 563 & 15 & 169 & 33 & 729 & 16 & 194 & 43 \\
\hline Breast & - & - & - & - & 9070 & 21 & 3094 & 42 \\
\hline Cervix uteri & - & - & - & - & 476 & 37 & 120 & 43 \\
\hline Corpus uteri & - & - & - & - & 1189 & 25 & 576 & 42 \\
\hline Ovary & - & - & - & - & 875 & 23 & 438 & 42 \\
\hline Prostate & 3930 & 20 & 4149 & 30 & - & - & - & - \\
\hline Kidney & 639 & 22 & 392 & 32 & 372 & 31 & 300 & 41 \\
\hline $\begin{array}{l}\text { Urinary } \\
\text { bladder }\end{array}$ & 855 & 25 & 1027 & 33 & 216 & 32 & 308 & 40 \\
\hline $\begin{array}{l}\text { Non-Hodgkin's } \\
\text { lymphoma }\end{array}$ & 1060 & 21 & 575 & 31 & 703 & 25 & 514 & 42 \\
\hline $\begin{array}{l}\text { Total of } \\
\text { these sites }\end{array}$ & 16510 & 23 & $1420 \mid$ & 34 & 19003 & 24 & 10097 & 42 \\
\hline
\end{tabular}

$\chi^{2}$ test. Logistic regression analyses of the odds of having a specific concomitant disease were performed age- and gender-adjusted for all tumour sites combined, and according to tumour site for four concomitant diseases separately; cardiovascular disease, COPD, diabetes mellitus, and gastrointestinal disease. Statistical significance of an overall effect of SES on the prevalence of a specific condition was tested using the $\chi^{2}$-likelihood ratio test. Crude 1-year survival rates were calculated for all studied tumours combined and for the most important tumour sites separately. Cox's regression models were used to compute multivariate rates (hazard ratio $=\mathrm{HR}$ ) and $95 \%$ confidence intervals $(95 \% \mathrm{CI})$. The relative contribution (\%) of adding comorbidity to the model was calculated as follows: ((HR model A-HR model B)/(HR model $A-1)) \times 100$, where $A$ is the basic model (age- and genderadjusted) and in model B comorbidity is added to model A. All statistical analyses were performed using SAS V9.12 (SAS Institute Inc., Cary, NC, USA).

\section{RESULTS}

Male cancer patients were older than female patients (Table 1), the median age being 69 and 64 years, respectively $(P<0.0001)$. At the time of the diagnosis of the cancer $71 \%$ of male and $58 \%$ of female cancer patients had at least one concomitant disease. The most frequent concomitant condition for males with cancer was cardiovascular disease (23\%), for women hypertension $(20 \%)$, among cancer patients older than 70 the prevalence of these diseases was $34 \%$ and $31 \%$, respectively. In the subgroup of cancer patients with two or more concomitant diseases, the most frequent combination of diseases among males was cardiovascular disease with hypertension (14\%) and in females diabetes with hypertension (21\%).

The proportion of patients by SES varied for the different tumour sites (Table 2). Patients under age 70 with stomach, lung, bladder, or cervical cancer more often had low SES. High SES was more frequent among patients with melanoma or breast, colorectal, or prostate cancer in this age group.

Among patients aged $70+$ with cancer of the oesophagus, stomach, or lung, low SES was clearly over-represented. High SES was more frequent among patients with prostate cancer or NHL.

For all tumour localisations the proportion of patients without comorbidity was highest in the high SES group (Figure 1). 

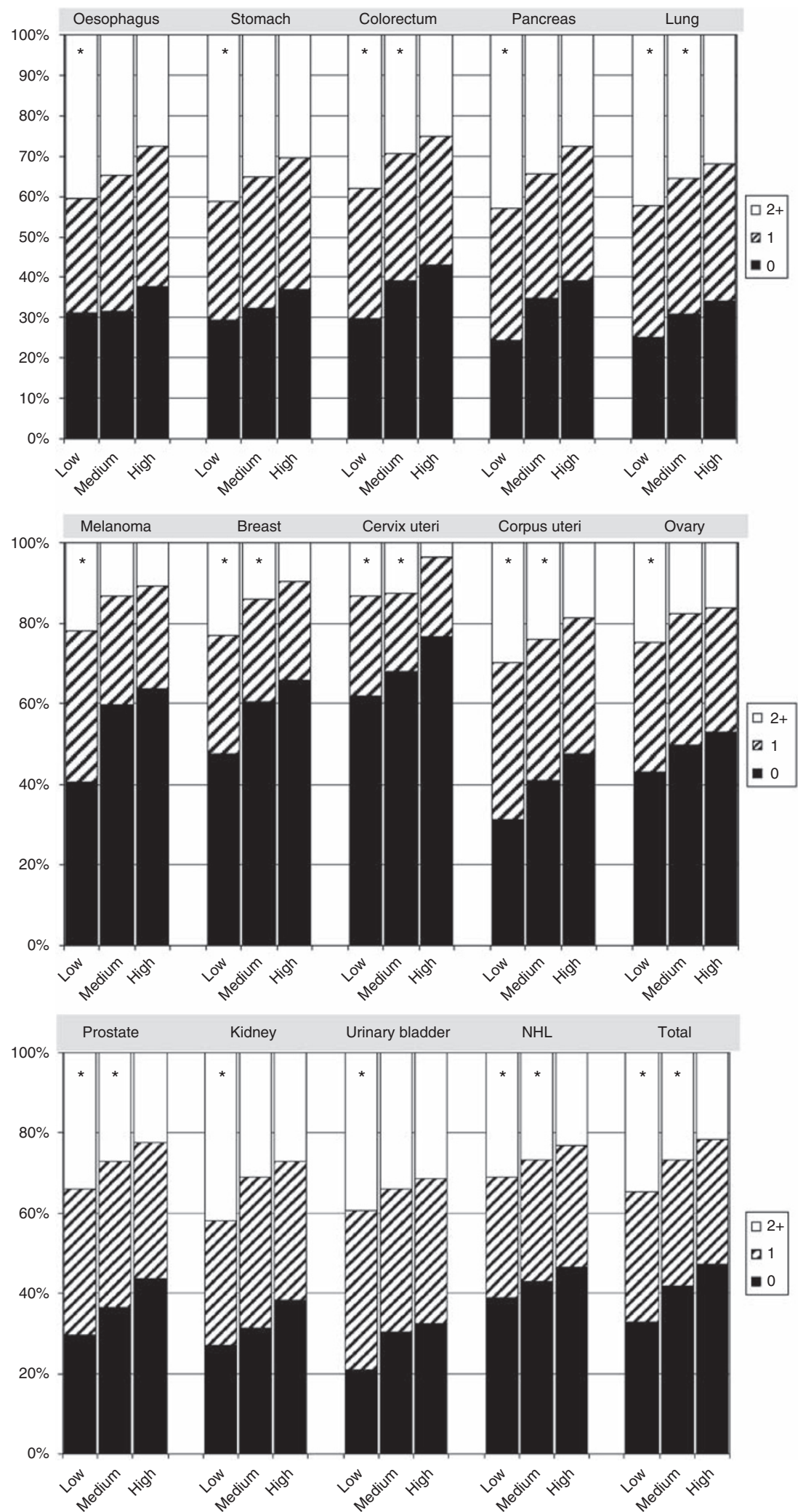

Figure I Number of concomitant diseases among cancer patients diagnosed in 1997-2006 in the Southeastern Netherlands. *Distribution of number of concomitant diseases significantly different from the highest socioeconomic status category.

A gradient towards more concomitant conditions appeared in lower SES groups $(P<0.001)$, which had a significantly higher risk of cardiovascular disease $\left(\mathrm{OR}_{\text {low }} v\right.$ s high $\mathrm{SES}=1.4,95 \% \mathrm{CI}$ : $1.3-1.5)$, $\mathrm{COPD}(\mathrm{OR}=1.8(1.7-1.9))$, diabetes mellitus $(\mathrm{OR}=1.5$
$(1.4-1.6))$, cerebrovascular disease $(\mathrm{OR}=1.5(1.4-1.7))$, tuberculosis $(\mathrm{OR}=1.3 \quad(1.1-1.6))$, dementia $(\mathrm{OR}=1.3 \quad(1.0-1.8))$, gastrointestinal disease $(\mathrm{OR}=1.5(1.4-1.6))$, and two or more concomitant conditions $(\mathrm{OR}=1.8(1.7-1.9))$ in addition to their 
Table 3 Risk of specific concomitant diseases according to SES adjusted for age and gender among cancer patients diagnosed in 1997-2006

\section{SES}

\begin{tabular}{lcccl} 
Concomitant disease & Low & Intermediate & High & $\mathbf{P}^{\mathbf{a}}$ \\
\hline Previous cancer & 1.01 & 0.99 & 1.00 & 0.7 \\
Cardiovascular disease & $1.42^{\mathrm{b}}$ & $1.23^{\mathrm{b}}$ & 1.00 & $0.000 \mathrm{I}$ \\
COPD & $1.81^{\mathrm{b}}$ & $1.37^{\mathrm{b}}$ & 1.00 & $0.000 \mathrm{I}$ \\
Hypertension & 0.98 & 1.03 & 1.00 & 0.2 \\
Diabetes mellitus & $1.52^{\mathrm{b}}$ & $1.32^{\mathrm{b}}$ & 1.00 & $0.000 \mathrm{I}$ \\
Cerebrovascular disease & $1.53^{\mathrm{b}}$ & $1.27^{\mathrm{b}}$ & 1.00 & $0.000 \mathrm{I}$ \\
Tuberculosis & $1.34^{\mathrm{b}}$ & 1.17 & 1.00 & 0.01 \\
Central nervous system & $1.34^{\mathrm{b}}$ & 1.05 & 1.00 & 0.05 \\
Gastrointestinal & $1.48^{\mathrm{b}}$ & $1.27^{\mathrm{b}}$ & 1.00 & $0.000 \mathrm{I}$ \\
Other & $1.22^{\mathrm{b}}$ & 1.10 & 1.00 & 0.01 \\
I or more concomitant disease & $1.50^{\mathrm{b}}$ & $1.24^{\mathrm{b}}$ & 1.00 & 0.0001 \\
2 or more concomitant diseases & $1.80^{\mathrm{b}}$ & $1.36^{\mathrm{b}}$ & 1.00 & $0.000 \mathrm{I}$ \\
\hline Abbrevis
\end{tabular}

Abbreviations: $\mathrm{COPD}=$ chronic obstructive pulmonary diseases; SES = socioeconomic status. ${ }^{\text {ap }}$ for overall effect of SES ( $\chi^{2}$-likelihood ratio). ${ }^{b}$ Confidence interval does not include 1.00
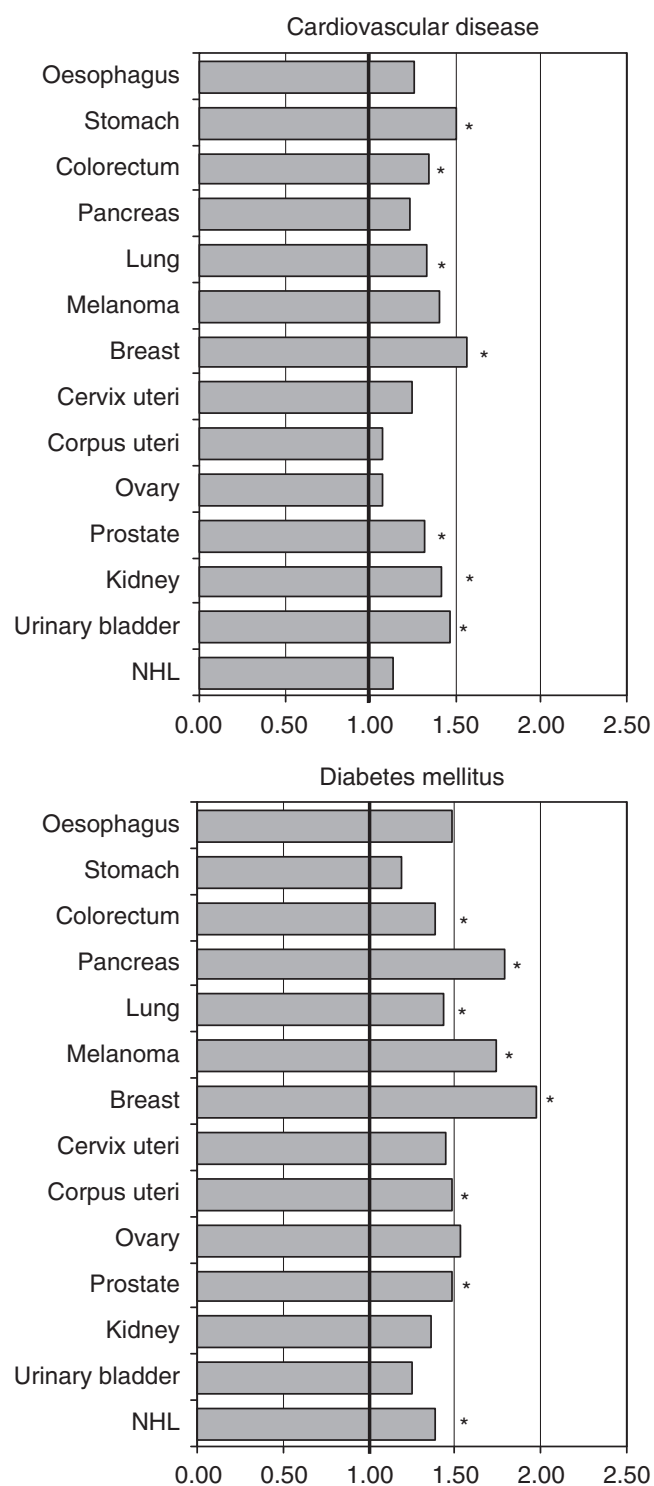

cancer (Table 3). The risk of having cancer and also at least one other serious concomitant disease was $50 \%$ higher in the low SES than in the high SES group $(\mathrm{OR}=1.5(1.4-1.6))$.

For four concomitant conditions we stratified by tumour localisation (Figure 2). The risk of cardiovascular disease among low compared with high SES patients was significantly higher (1.4-1.6 times) for patients with stomach, colorectal, lung, breast, prostate, and bladder cancer. The risk of COPD was elevated among low SES patients with cancer of the stomach, colorectum, pancreas, lung, breast, corpus uteri, prostate, and kidney (OR's ranging from 1.4 to 2.2). The risk of diabetes mellitus was highest among people from low SES with breast cancer $(\mathrm{OR}=2.0(1.2-2.4))$ and the risk of gastrointestinal diseases was highest among patients with oesophageal cancer $(\mathrm{OR}=2.0$ $(1.2-3.4))$

Crude 1-year survival of cancer patients from lower SES was worse compared with the highest SES for all tumour sites combined and for the major sites separately (Table 4). The ageadjusted risk of death was significantly elevated for both men $\left(\mathrm{HR}_{\text {low }} v\right.$ s high $\left.\mathrm{SES}=1.40,95 \% \mathrm{CI}: 1.3-1.4\right)$ and women $(\mathrm{HR} 1.40$ $(1.3-1.5))$. Adding comorbidity to the model reduced HR to 1.35
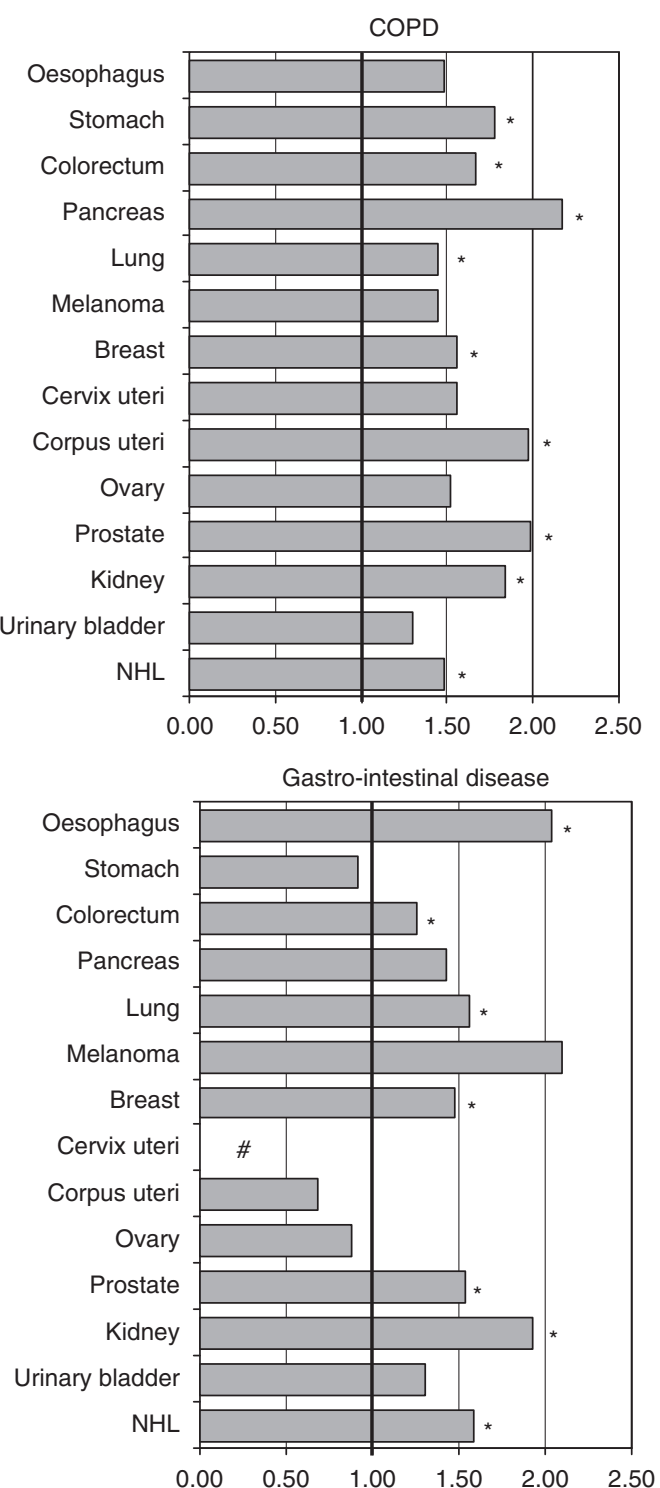

Figure 2 Risk of four concomitant diseases among cancer patients with the lowest socioeconomic status (SES) compared with those with the highest SES (= reference, 1.00) according to tumour localisation with adjustment for age and gender. *95\% confidence interval does not include I.00; \# No reliable estimate because $<5$ cases in reference category. 
Table 4 Crude survival, risk of death, and contribution of comorbidity to risk of death according to tumour site and SES among cancer patients diagnosed in 1997-2006

\begin{tabular}{|c|c|c|c|c|c|c|}
\hline & \multicolumn{3}{|c|}{ I-year survival rate (\%) } & \multirow{2}{*}{$\frac{\text { Model } A^{a}}{\operatorname{HR}^{c}(95 \% C l)}$} & \multirow{2}{*}{$\frac{\text { Model B }}{\text { HR }^{\mathrm{a}}(95 \% \mathrm{CI})}$} & \multirow{2}{*}{$\begin{array}{c}\text { Relative contribution } \\
\text { comorbidity }^{\mathbf{b}}\end{array}$} \\
\hline & Low SES & Inter-mediate & High SES & & & \\
\hline \multicolumn{7}{|l|}{ Males } \\
\hline Colorectum & 72 & 78 & 78 & $1.13(1.0-1.3)$ & $1.10(1.0-1.3)$ & $23 \%$ \\
\hline Lung & 36 & 39 & 41 & $1.11(1.0-1.2)$ & $1.11(1.0-1.2)$ & $0 \%$ \\
\hline Prostate & 90 & 94 & 95 & $1.47(1.2-1.8)$ & $1.36(1.1-1.7)$ & $22 \%$ \\
\hline Total $^{d}$ & 59 & 66 & 70 & $1.40(1.3-1.5)$ & $1.35(1.3-1.4)$ & $12 \%$ \\
\hline \multicolumn{7}{|l|}{ Females } \\
\hline Colorectum & 74 & 78 & 79 & $1.09(0.9-1.3)$ & $1.06(0.9-1.2)$ & $33 \%$ \\
\hline Lung & 41 & 42 & 46 & $1.09(1.0-1.2)$ & $1.09(1.0-1.2)$ & $0 \%$ \\
\hline Breast & 94 & 97 & 98 & $1.68(1.3-2.2)$ & $1.56(1.2-2.0)$ & $18 \%$ \\
\hline Total $^{d}$ & 74 & 81 & 84 & $1.40(1.3-1.5)$ & $1.34(1.3-1.4)$ & $15 \%$ \\
\hline
\end{tabular}

a Model A: adjusted for age, Model B: adjusted for age and the presence of concomitant diseases (yes vs no). ${ }^{\mathrm{b}}((\mathrm{HR}$ model $\mathrm{A}-(\mathrm{HR}$ model $\mathrm{A}+\mathrm{comorbidity}) /(\mathrm{I}-\mathrm{HR}$ model A)) $\times$ 100. 'Hazard Ratio (HR) of lowest socioeconomic status (SES) group compared with highest (= reference). ${ }^{\mathrm{d} A l l}$ studied sites combined (oesophagus, stomach, colorectum, pancreas, lung, melanoma, breast, cervix uteri, corpus uteri, ovary, prostate, kidney, urinary bladder, non-Hodgkin's lymphoma).

for men and 1.34 for women. The relative contribution of comorbidity in explaining the inequality in 1-year survival varied from $0 \%$ for lung cancer to $33 \%$ among female colorectal cancer patients.

\section{DISCUSSION}

To our knowledge, this is the first large population-based study to demonstrates the impact of SES on the prevalence of concomitant diseases among cancer patients, with increased prevalence of comorbidity in lower socioeconomic strata for each type of cancer. Cancer patients with low SES had a $50 \%$ higher risk of suffering from at least one other serious disease compared with those with high SES. The prevalence of comorbidity was significantly higher with newly diagnosed cancer of lower compared with higher SES for all 14 cancer sites studied. The diseases significantly related to SES among cancer patients were cardiovascular disease, COPD, diabetes mellitus, cerebrovascular disease, tuberculosis, diseases of the central nervous system, and gastrointestinal disease. Although both the prevalence of comorbidity and the proportional distribution of SES vary significantly among tumour types, the gradient of more comorbidity from high to low SES was apparent among all tumour types.

Smoking is probably responsible for the higher risk of cardiovascular disease, COPD, and cerebrovascular disease among low SES groups (Doll et al, 1994; Stellman and Resnicow, 1997). This is confirmed by the higher prevalence of those diseases among patients with smoking-related tumours: cancers of the stomach, lung, bladder, and kidney (Janssen-Heijnen et al, 1998; Koppert et al, 2004). Diabetes was more frequent among low SES for patients with cancers of the colorectum, pancreas, lung, breast, corpus uteri or prostate, or melanoma or NHL. Diabetes has been linked to pancreas cancer (Jain et al, 1991; Kalapothaki et al, 1993) either as a risk factor or as the clinical manifestation of the cancer itself (Warshaw and Fernandez-del Castillo, 1992). Diabetes has also been associated with an increased risk for breast (Xue and Michels, 2007), endometrial (Parazzini et al, 1991), and colorectal cancer (Polednak, 2006) probably because of a relation with obesity (Reeves et al, 2007). Substantial evidence exists for the association of obesity with low SES (Sobal and Stunkard, 1989; Wardle et al, 2002; McLaren, 2007).

The prevalence of gastrointestinal diseases was highest for low SES patients with oesophageal, colorectal, lung, breast, prostate or kidney cancer, or NHL. Oesophageal cancer has also been associated with gastrointestinal diseases (Koppert et al, 2004). A lower consumption of vegetables, fruit, and fibres, which may protect from oesophageal (Tzonou et al, 1996; Terry et al, 2001b) and colorectal cancer (Pietinen et al, 1999; Michels et al, 2000; Voorrips et al, 2000; Terry et al, 2001a; Bueno-de-Mesquita et al, 2002; Flood et al, 2002), has been reported among lower SES (Wallstrom et al, 2000; Hulshof et al, 2003; Wardle and Steptoe, 2003).

We used an indicator of SES based on the postal code of a residential area. This aggregate covers a very small geographical area, and thus represents a reliable approximation of individual SES. Furthermore, routinely collected income tax data (no questionnaires or interviews) have been found to provide reliable estimates of household income. Previous studies have proven that socioeconomic differences based on neighbourhood data tend to reflect such differences well at the individual level (Bos et al, 2000, 2001; Smits et al, 2001). Furthermore, this objective measure of SES is also applicable to older women (born before 1955), whose occupation or education does not always properly reflect their social class (Berkman and Macintyre, 1997).

Previously, we found that patients with comorbidity were often treated less aggressively, if alternative treatment strategies were available. Except for patients with a tumour with poor survival, comorbidity has an independent prognostic effect (Janssen-Heijnen et al, 2005). This negative impact of comorbidity on survival of cancer might have several mechanisms: the increased risk of death due to the comorbid condition itself, more contra-indications for the cancer treatment, more indications for dose reduction and a higher rate of treatment-related complications such as infections and cardiovascular events. In several of our recent studies, the adverse effects of comorbidity on survival appeared to be independent of treatment, so less aggressive treatment could not (fully) account for the observed differences in survival between patients with and without comorbidity (Post et al, 2001; Lemmens et al, 2005; Louwman et al, 2005; van Spronsen et al, 2005; Houterman et al, 2006). As SES represents a combination of lifestyle, health, and risk of suboptimal treatment, cancer patients with comorbidity could also (partly) explain the poorer prognosis. Although an in-depth study remains necessary to reveal whether stage at diagnosis and treatment contributed to the SES gradient in survival, also for longer survival periods, our preliminary analyses demonstrated a clear gradient in 1-year survival rates, which could partly be attributed to comorbidity. 
Our study shows considerable variation in comorbidity by tumour type and a higher risk of concomitant disease among patients from lower SES. Given the aetiology of the type of tumours as well as the aetiology of the concomitant diseases that occur more frequently among patients from low SES background, a lot can probably be gained from preventive measures related to lifestyle (such as smoking and obesity). Considering survival is worse for patients of low SES, our

\section{REFERENCES}

Ayanian JZ, Zaslavsky AM, Fuchs CS, Guadagnoli E, Creech CM, Cress RD, O'Connor LC, West DW, Allen ME, Wolf RE, Wright WE (2003) Use of adjuvant chemotherapy and radiation therapy for colorectal cancer in a population-based cohort. J Clin Oncol 21: $1293-1300$

Berkman LF, Macintyre S (1997) The measurement of social class in health studies: old measures and new formulations. IARC Sci Publ 138: 51 - 64

Bos V, Kunst AE, Mackenbach JP (2000) Nationale gegevens over sociaaleconomische sterfteverschillen op basis van informatie over kleine geografische eenheden. Verslag aan de programmacommissie Sociaaleconomische gezondheidsverschillen II. Instituut Maatschappelijke Gezondheidszorg, Erasmus Universiteit: Rotterdam

Bos V, Kunst AE, Mackenbach JP (2001) De omvang van sociaaleconomische sterfteverschillen gemeten op buurtniveau: vergelijking met schattingen op basis van informatie op individueel niveau. In Sociaal-economische gezonheidsverschillen: Van verklaren naar verkleinen, Stronks K (ed) Vol. 5, pp 8-20. Zon/MW: Den Haag

Bueno-de-Mesquita HB, Ferrari P, Riboli E (2002) Plant foods and the risk of colorectal cancer in Europe: preliminary findings. IARC Sci Publ 156: 89-95

Charlson ME, Pompei P, Ales KL, MacKenzie CR (1987) A new method of classifying prognostic comorbidity in longitudinal studies: development and validation. I Chronic Dis 40: $373-383$

Dalton SO, Schuz J, Engholm G, Johansen C, Kjaer SK, Steding-Jessen M, Storm HH, Olsen JH (2008) Social inequality in incidence of and survival from cancer in a population-based study in Denmark, 1994-2003: summary of findings. Eur J Cancer 44(14): 2074-2085

Doll R, Peto R, Wheatley K, Gray R, Sutherland I (1994) Mortality in relation to smoking: 40 years' observations on male British doctors. Br Med J 309: 901 - 911

Flood A, Velie EM, Chaterjee N, Subar AF, Thompson FE, Lacey Jr JV, Schairer C, Troisi R, Schatzkin A (2002) Fruit and vegetable intakes and the risk of colorectal cancer in the Breast Cancer Detection Demonstration Project follow-up cohort. Am J Clin Nutr 75: 936-943

Houterman S, Janssen-Heijnen ML, Hendrikx AJ, Berg HA, Coebergh JW (2006) Impact of comorbidity on treatment and prognosis of prostate cancer patients: A population-based study. Crit Rev Oncol Hematol 58: $60-67$

Hulshof KF, Brussaard JH, Kruizinga AG, Telman J, Lowik MR (2003) Socio-economic status, dietary intake and $10 \mathrm{y}$ trends: the Dutch National Food Consumption Survey. Eur J Clin Nutr 57: 128-137

Jain M, Howe GR, St Louis P, Miller AB (1991) Coffee and alcohol as determinants of risk of pancreas cancer: a case-control study from Toronto. Int J Cancer 47: 384-389

Janssen-Heijnen ML, Houterman S, Lemmens VE, Louwman MW, Maas HA, Coebergh JW (2005) Prognostic impact of increasing age and co-morbidity in cancer patients: a population-based approach. Crit Rev Oncol Hematol 55: $231-240$

Janssen-Heijnen ML, Schipper RM, Razenberg PP, Crommelin MA, Coebergh JW (1998) Prevalence of co-morbidity in lung cancer patients and its relationship with treatment: a population-based study. Lung Cancer 21: $105-113$

Janssen-Heijnen ML, Smulders S, Lemmens VE, Smeenk FW, van Geffen HJ, Coebergh JW (2004) Effect of comorbidity on the treatment and prognosis of elderly patients with non-small cell lung cancer. Thorax 59: $602-607$

Jemal A, Thun MJ, Ward EE, Henley SJ, Cokkinides VE, Murray TE (2008) Mortality from leading causes by education and race in the United States, 2001. Am J Prev Med 34: 1-8

Kalapothaki V, Tzonou A, Hsieh CC, Toupadaki N, Karakatsani A, Trichopoulos D (1993) Tobacco, ethanol, coffee, pancreatitis, diabetes results stress the need for reduction of socioeconomic differences in health.

\section{ACKNOWLEDGEMENTS}

Supported by a grant from the Dutch Cancer Society (IKZ 2000-2260). mellitus, and cholelithiasis as risk factors for pancreatic carcinoma. Cancer Causes Control 4: 375-382

Koppert LB, Janssen-Heijnen ML, Louwman MW, Lemmens VE, Wijnhoven BP, Tilanus HW, Coebergh JW (2004) Comparison of comorbidity prevalence in oesophageal and gastric carcinoma patients: a population-based study. Eur J Gastroenterol Hepatol 16: 681-688

Lahelma E, Rahkonen O, Berg MA, Helakorp S, Prattala R, Puska P, Uutela A (1997) Changes in health status and health behavior among Finnish adults 1978-1993. Scand J Work Environ Health 23(Suppl 3): $85-90$

Lash TL, Thwin SS, Horton NJ, Guadagnoli E, Silliman RA (2003) Multiple informants: a new method to assess breast cancer patients' comorbidity. Am J Epidemiol 157: 249-257

Lemmens VE, Janssen-Heijnen ML, Verheij CD, Houterman S, Repelaer van Driel OJ, Coebergh JW (2005) Co-morbidity leads to altered treatment and worse survival of elderly patients with colorectal cancer. Br J Surg 92: $615-623$

Louwman WJ, Janssen-Heijnen ML, Houterman S, Voogd AC, van der Sangen MJ, Nieuwenhuijzen GA, Coebergh JW (2005) Less extensive treatment and inferior prognosis for breast cancer patient with comorbidity: a population-based study. Eur J Cancer 41: 779-785

Mackenbach JP, Stirbu I, Roskam AJ, Schaap MM, Menvielle G, Leinsalu M, Kunst AE (2008) Socioeconomic inequalities in health in 22 European countries. $N$ Engl J Med 358: $2468-2481$

McLaren L (2007) Socioeconomic status and obesity. Epidemiol Rev 29: $29-48$

Michels KB, Edward G, Joshipura KJ, Rosner BA, Stampfer MJ, Fuchs CS, Colditz GA, Speizer FE, Willett WC (2000) Prospective study of fruit and vegetable consumption and incidence of colon and rectal cancers. J Natl Cancer Inst 92: 1740-1752

Parazzini F, La Vecchia C, Bocciolone L, Franceschi S (1991) The epidemiology of endometrial cancer. Gynecol Oncol 41: 1-16

Pietinen P, Malila N, Virtanen M, Hartman TJ, Tangrea JA, Albanes D, Virtamo J (1999) Diet and risk of colorectal cancer in a cohort of Finnish men. Cancer Causes Control 10: $387-396$

Polednak AP (2006) Comorbid diabetes mellitus and risk of death after diagnosis of colorectal cancer: a population-based study. Cancer Detect Prev 30: $466-472$

Post PN, Hansen BE, Kil PJ, Janssen-Heijnen ML, Coebergh JW (2001) The independent prognostic value of comorbidity among men aged $<75$ years with localized prostate cancer: a population-based study. BJU Int 87: $821-826$

Reeves GK, Pirie K, Beral V, Green J, Spencer E, Bull D (2007) Cancer incidence and mortality in relation to body mass index in the Million Women Study: cohort study. Br Med J 335: 1134

Siemiatycki J, Krewski D, Franco E, Kaiserman M (1995) Associations between cigarette smoking and each of 21 types of cancer: a multi-site case-control study. Int J Epidemiol 24: 504-514

Smits J, Keij I, Westert G (2001) Effecten van sociaal-economische status van kleine, middelgrote en grote geografische eenheden op de sterfte. Mndstat bevolking 11: 4-10

Sobal J, Stunkard AJ (1989) Socioeconomic status and obesity: a review of the literature. Psychol Bull 105: 260-275

Stellman SD, Resnicow K (1997) Tobacco smoking, cancer and social class. IARC Sci Publ 229-250

Stronks K, van de Mheen HD, Looman CW, Mackenbach JP (1997) Cultural, material, and psychosocial correlates of the socioeconomic gradient in smoking behavior among adults. Prev Med 26: 754-766

Terry P, Giovannucci E, Michels KB, Bergkvist L, Hansen H, Holmberg L, Wolk A (2001a) Fruit, vegetables, dietary fiber, and risk of colorectal cancer. J Natl Cancer Inst 93: 525-533 
Terry P, Lagergren J, Hansen H, Wolk A, Nyren O (2001b) Fruit and vegetable consumption in the prevention of oesophageal and cardia cancers. Eur J Cancer Prev 10: 365-369

Tyczynski JE, Bray F, Parkin DM (2003) Lung cancer in Europe in 2000: epidemiology, prevention, and early detection. Lancet Oncol 4: 45-55

Tzonou A, Lipworth L, Garidou A, Signorello LB, Lagiou P, Hsieh C, Trichopoulos D (1996) Diet and risk of esophageal cancer by histologic type in a low-risk population. Int J Cancer 68: 300-304

van Duijn C, Keij I (2002) Sociaal-economische status indicator op postcode niveau. Maandstatistiek van de bevolking 50: $32-35$

van Spronsen DJ, Janssen-Heijnen ML, Lemmens VE, Peters WG, Coebergh JW (2005) Independent prognostic effect of co-morbidity in lymphoma patients: results of the population-based Eindhoven Cancer Registry. Eur J Cancer 41: 1051 - 1057

Voorrips LE, Goldbohm RA, van Poppel G, Sturmans F, Hermus RJ, van den Brandt PA (2000) Vegetable and fruit consumption and risks of colon and rectal cancer in a prospective cohort study: The Netherlands Cohort Study on Diet and Cancer. Am J Epidemiol 152: $1081-1092$

Wallstrom P, Wirfalt E, Janzon L, Mattisson I, Elmstahl S, Johansson U, Berglund G (2000) Fruit and vegetable consumption in relation to risk factors for cancer: a report from the Malmo Diet and Cancer Study. Public Health Nutr 3: 263-271

Wardle J, Steptoe A (2003) Socioeconomic differences in attitudes and beliefs about healthy lifestyles. J Epidemiol Community Health 57: $440-443$

Wardle J, Waller J, Jarvis MJ (2002) Sex differences in the association of socioeconomic status with obesity. Am J Public Health 92: $1299-1304$

Warshaw AL, Fernandez-del Castillo C (1992) Pancreatic carcinoma. $N$ Engl J Med 326: $455-465$

Xue F, Michels KB (2007) Diabetes, metabolic syndrome, and breast cancer: a review of the current evidence. Am J Clin Nutr 86: s823-s835 